

\title{
Representations of mothering of migrant Finns
}

\author{
Minna Zechner and Tiina Tiilikka
}

\section{Introduction}

Viewing a welfare state as a normative project means that moral conceptions, values, and social goals are expressed and, to some extent, also shared. The Nordic welfare states have been seen as promoters of principles such as equality, public responsibility for welfare, and work for all (Julkunen, 2017; Kildal and Kuhnle, 2005). The broad normative ideas behind welfare states are often hard to find in the everyday practices of welfare state institutions such as day care or child welfare clinics. However, public services and benefits are not only aimed at increasing the welfare of the citizens, but they also give individuals, families, and communities overt and covert guidance on how to be a good member of the given society - or even a good parent (Hiitola, 2015).

Learning these norms and related values takes time (Baldock, 2007, p.68), and learned values may travel with migrants when moving to another country. In the new home country, the old and the new norms are seen as merging, conflicting, and reconfiguring (Zechner and Tiilikka, 2020). Norms are also changing since the normative borders of the welfare states are constantly in flux. These borders are constructed in historical settings, being products of interaction and negotiations between interest groups that shape the territorially based welfare states. However, borders function to fix meanings and to constitute fields of knowledge (Altink and Weedon, 2010, pp.2-6).

In this chapter we focus on understandings of good parenthood and especially on good motherhood or mothering, which are presented by migrant Finns living outside Finland. We study mothering by analysing migrant mothers' blog texts where they talk about their everyday lives outside Finland. The bloggers have migrated from Finland as adults, so they have positioned themselves in connection to the values and norms related to parenting and mothering that the Finnish welfare state promotes. These bloggers now live in a context of another country and may thus compare, choose, mix, and create new norms for mothering. We see their blogging as part of their transnational subjectivity, meaning that international mobility is part of their personal history, and influences their choices and ways of living (Zechner, 2017).

Blogging is a part of the mothers' transnational activities. The blog texts that comprise our data are written by five Finnish mothers living outside Finland in capitalist societies, and many of them have extensive social programmes. The analysis focuses on the representations of good mothering and on the comparisons done on the norms of parenting in Finland and in the country of residence. We pay special attention to the use of family services and benefits that are likely to reveal the local norms by requiring certain kinds of behaviours, such as giving vaccinations to a child or breastfeeding. These encounters also have the potential to bring out evaluations regarding the norms of good parenting. This chapter aims to answer the questions: how is good mothering presented in blog texts? In which ways are different society-specific norms present in representations of mothering? What kinds of differences are brought up by the blogging mothers? By answering these questions, we will analyse the borders of the norms of parenting.

Using material archived online, we are exploring the representational world of individuals. The internet is here seen as a site for the cultural production of texts (Bassett and O'Riordan, 2002, p.235), and the bloggers as authors creating online content. This study draws on research that focuses on a representational world located not only on the internet (Iseke-Barnes and Danard, 2007), but also at the intersection of different countries and norms of mothering (Baldassar and Merla, 2014; Kremer, 2007).

\section{In search of representations in blog texts}


The data in this study consists of blogs where dated entries are posted in reverse chronological order. The blog texts are written by Finnish women who live outside Finland with their families. According to Lori Lopez (2009), "mummy blogging” gives women possibilities to share and support one another, but the genre itself can also position the mothers into the traditional role of a mother. In migrant blogs, individuals often document their adaptation to a new environment and a new life. Migrant blogs are often written in native languages and in this way they help to maintain contacts with the country of origin and to share experiences with others who may be interested in moving abroad (Popow, 2016, p.333).

Blogs are published in blog services where anybody with the required skills may set up a blog. We searched the blog texts in Google and by using a Finnish blog list (https://www.blogit.fi/) and a blog search engine (http://www.blogsearchengine.org/). The search words included mother, father, family, parenthood, children, and Finns living abroad (ulkosuomalainen in Finnish). Despite our efforts, no blogs written by Finnish fathers were found. However, in one of the blogs featured in our data, a Finnish father wrote a text as a guest writer on his wife's blog.

Out of the returned blogs we found, we chose the ten most active and contacted the bloggers. Of these, five bloggers gave us permission to use their texts. We received five signed permissions from bloggers who lived in Denmark, France, Holland, Turkey, and the United Kingdom. These permissions allow us to use their texts published between January and April 2018 as data for our research to publish excerpts of their texts in publications, to refer to the blog texts with the title of the blog, and to list the blogs at the end of the article with online addresses.

The writers of these five blogs present themselves as Finnish women and mothers who live outside Finland. One of them lived in the United Kingdom only during the time the data collection was done. Three of them were working during the time of the data collection. They are educated individuals who have emigrated from Finland of their own free will because of work, studies, or their partners. Two of them are in their forties, while the others are probably around their thirties. They all have male partners and one to two biological children ranging from small babies to children of about ten years of age. One of the bloggers also has two stepchildren who seem to be teenagers. They have started the blogs between 2008 and 2018, and they publish texts in Finnish every month. Blogtexts include descriptions of their everyday lives as women and mothers outside Finland. One of the bloggers writes about her chronic illness. The photos that feature in their blogs are not analysed here.

The analysis is based on those parts of the blog texts that focus on children, family, parenting, mothering, and the use of social, health, and educational services. The amount of text consists of 58 posts that equate to 83 pages, and from 8 to 17 posts per blogger. The blogs are listed under the heading of data at the end of this chapter. We mention the country of residence in connection to the quotes in order to distinguish between different bloggers. The translations of the quotes are our own.

We use representation as our analytical concept. Signs, words, mental images, and conceptions are representing and thus presenting something that is outside of them (Knuuttila and Lehtinen, 2010). Representation is an act or an event, for example the act of telling about experiences in the form of a blog text so that meanings are attached to images, objects, and people. At the same time, these meanings are connected and associated with the surrounding world and the social relations within it.

After thorough reading of the blogs, we coded the data in line with the research questions that relate to parenting, mothering, migration, and the welfare state. By coding, we mean a process of organizing data so that relevant phenomena are made visible. Coding consists of conceptualizing, raising questions, thinking of connections between different matters in the data, and getting to know the data (Coffey and Atkinson, 1996, p.28-31). Our coding resulted in three main themes of representations of mothering. These themes are not clear-cut and overlap at times, and include the following domains: parenthood on the societal level, parental decisions and decision-making, and the division of labour within the family and in the respective societies. Next, we explain the themes in more detail. 


\section{Parenthood on the societal level}

The first theme is about the guidelines, services, and norms related to parenting and raising children. We investigate what values the bloggers see as being taught to their children at the local school and in the surrounding society. Here, the connection to transnational life and differing countries and welfare states is most obvious when the bloggers compare instructions given by professionals regarding childcare or upbringing. Of the five bloggers, the mother in Turkey elaborates most on this theme. She describes how, as her child has grown older, she needs to be more alert about what her child is saying to other children:

I had a pretty clear vision that the girl will be raised to respect older persons, nature, those who are of different colour and size, animals and that the truth is spoken to her. When she was a baby one did not need to think that when telling her the truth, she would shout it out to other children in the school yard and that this would then lead to awkward situations. Those topics that are sensitive to Turkish people are also sensitive when raising a child. (Turkey)

When raising children in a societal context that is different from the one where the parent grew up, it may be challenging to retain and pass on one's own values to the children. This is a phenomenon often studied in the context of non-Western families living in a Western world (e.g. Strandbu, 2005). As a parent, the mother in Turkey needs to balance between acculturation and enculturation. Acculturation refers to engaging and adjusting to the dominant culture in Turkey, while enculturation means the socialization with one's own culture (Inman et al., 2007). In line with other Nordic countries, Finland emphasizes gender equality and anti-discrimination - values internalized by the mother in Turkey. However, the everyday life in Turkey has taught the mother that not everybody can be trusted. It is difficult to balance these conflicting values and to ensure that the daughter is not getting into trouble at school when vocalizing values that may seem unfit for the Turkish school. The blog is therefore a site to discuss and evaluate the ambivalence and discomfort that this balancing brings into motherhood.

Another school-related notion was brought up by a mother living in Denmark writing about her son being shunned from a circle of friends at school:

My son lives in this Danish cultural context where you are not supposed to demand attention. He has however experienced discrimination and he feels bad about it. In a Danish way he has suppressed his own unpleasant feelings and attempted to focus on positive things. (Denmark)

The mother living in Denmark sees that the son has adjusted to the Danish way of handling difficulties, or rather not handling unpleasant matters at all in school. Elsewhere she noted that the school had not taken enough action to handle the situation. There are no direct comparisons between how these issues would be handled in Finland. However, the mother reveals (in another text) having had similar experiences in her youth in Finland, and therefore she is trying everything she can to make the situation better for her son. The mother's gendered task is often to secure the psychological well-being and development of her child (Vuori, 2003, p.45), even if the schools or other welfare institutions seem unresponsive.

The mother living in the United Kingdom paid attention to school practices as well, even though her child was not yet attending school.

I feel chilly watching the teacher lead the schoolchildren on foot to a church nearby. The teacher has a proper coat and often even a hat, but the children only wear school uniforms. (United Kingdom)

The implicit comparison connects the excerpt to the Finnish welfare state. Playing outside in all types of weather and wearing weather-appropriate attire is very much promoted for children in Finland. Finnish shops offer an abundant selection of weatherproof gear and parents are socialized into providing proper clothing for their children already in day care and preschool (Smeds, 2017, p.44). Here, the disapproval is not towards British parenting, but rather the schooling system. The strangeness of the practice is underlined by the observation that the teacher (the professional) is her/himself properly dressed for the weather, and reflects a 
system where everybody needs to look after themselves. The school takes no responsibility for whether the children are properly dressed or not. During the last decades, individual responsibility has been increasingly emphasized in welfare state reforms in the United Kingdom as well as in Finland (e.g. Wright, 2016). With some matters, individual responsibility is less stressed:

I have been, amongst other things, wondering that while in Holland they recommend whole milk for children under four, in Finland they recommend fat-free milk. We follow the local instructions maybe the Dutch light-ish bread-based lunch balances the fatty milk-diet? (Holland)

At least in developed countries, parents of small babies are confronted with floods of instructions on how to feed their children. This often already starts when the mother is pregnant. The mother living in Holland is aware of the differences between Finnish and Dutch food recommendations and admits to following the Dutch recommendations. She still takes the time to rationalize the choice by bringing up the light lunch as a balancing factor relative to a fatty drink. The norm is that a good mother is able to provide what the child needs (Perälä-Littunen, 2004, p.106) and a considerate and rational mother pays attention to what food she gives to her toddler. It is also possible that it is more difficult to deviate from the local guidelines than to deviate from Finnish ones that are more distant.

\section{Parental decision-making}

The second theme consists of decisions and decision-making, in particular, how decisions related to children and parenting are made, what the sources of information are, and how different pieces of information are weighed in relation to each other.

Parenting is a sequence of endless decisions ranging from everyday choices of food and rhythms of life, to choosing what language to speak to the children and what vaccinations should or should not be given. Some of these decisions relate to the maternal body as well:

Earlier on I mentioned that I had already received at the maternity hospital a referral for pelvic muscle rehabilitation. ... We shall see how it is in the following times. Even though this is an important issue, it feels a bit odd to me that one really has to go to the midwife ten times for the workout even though this is an important issue. (France)

Earlier in her blog, the mother in France explained how she had heard that mothers in Finland are taught and sometimes pressured to breastfeed at the maternity hospitals. In French maternity hospitals, the pelvic muscle condition of the mother is emphasized instead. The comparison is implicit and features at different times in her blog. It nicely reflects how the Finnish welfare state promotes mothers first and foremost as mothers to their babies. Mothers are presented as milk-producing objects that need to function in line with the needs of the baby (see Wall, 2001). The French welfare state in this comparison defines mothers as individuals and women who have the need for bladder control and sexual pleasure. When the focus is placed on the needs of the mother, they are seen more as subjects (Jeremiah, 2006, p.24), albeit possibly concurrent with the needs of their partners.

In terms of education, the needs of the children seem to be defined globally in very similar ways:

When I started a year and a half ago at the kindergarten as an English teacher, I did not know what I was getting into. I did not see the idea as very sensible - teaching English to 2-6-year-olds every day. My mind has changed when I have been following children's development and enthusiasm. (Turkey)

Both in Turkey and in Finland there is an increasing emphasis on learning foreign languages at an earlier age. In Finland, English learning used to start in third grade, the year that children turn to nine years of age. However, in 2018 the Ministry for Education and Culture made a decision that first foreign language studies would start in the first grade (Opetus- ja kulttuuriministeriö, 2018). The mother living in Turkey who is both a professional in kindergarten and also a mother has accepted these changes, at least in her workplace. 
The mother in the United Kingdom describes how the Finnish welfare state emphasizes the benefits of fresh air and outdoors for children of all ages in parenthood education (see also Tourula Isola and Hassi, 2008).

She narrates that:

[In the UK] ... people observe the weather intensively. The next day is planned according to weather, contrary to Finland. No matter whether it rained or shone [baby's nickname] slept outside. (United Kingdom)

One of the recommendations in Finland is that small babies sleep outside, usually in the pram, and the mother living in the United Kingdom is a firm supporter of this practice, although in other parts of the blog she also reveals being warned of the dangers involved. This example shows that mothering is a "set of ideas and behaviours that are mutable, contextual" (Jeremiah, 2006, p.21). Outdoor sleeping is generally seen as safe and recommended in Finland, but not necessarily in the United Kingdom. Migrant mothers need to evaluate the information and knowledge learned in Finland against their contexts of present living, and at times there is a need to adjust the practices when living in a different country.

\section{Division of labour}

The third theme concerns the division of labour within the family and in the societies where the mothers live or have lived. There are only a few references to partners, their fathering, and the division of labour. Instead, the mothers rather often point out how important the mother is for the child. The distinction between the mother and the father as educators for their child is considered by the mother living in Turkey:

Fortunately, for the father of the girl, praising and praising and praising is more natural than for me. In my own teaching group, the most competitive children get the most attention. Even if I try to squeak that this is not a competition, it often seems to develop into one. As a Finn, it is foreign for me to encourage children to compete, but in a Turkish society it is vital. (Turkey)

The school is a context that reveals how the child has been raised at home. The mother living in Turkey emphasizes equal participation, but her experiences lead her to believe that Turkish school children are strongly encouraged to compete, and to seek attention and praise. In the family division of labour, the father is seen as capable of encouraging and praising the child. In Finnish schools, praising children has not been a key element. Instead, and especially earlier on, the children have been educated to be modest, and during recent decades increasingly independent citizens (Böök, 2010).

Raising children to be independent did not prevent one of the bloggers needing to consult her partner whether to blog or not. In the blog of the mother living in the United Kingdom, the father of the child was a guest writer. This is the only male writer we found. In his blog post, the father describes his feelings concerning the partner's blogging:

To be honest, I was first strongly resisting [partner's name] blog. I did not,however, voice it. I thought that if she gets joy from writing about the daily life with a baby and a channel to vent her hard experiences, then who am I to take that away from her? After all, we live in the year 2018 when public blogs are a natural way to share thoughts. My partner's idea was to write about taboos of motherhood, premature baby and childlessness at a general level, but obviously it ends up being rather personal. (United Kingdom)

The partner first showed concern about whether the mother in the United Kingdom published content which was too intimate or personal. Blogs are part of a public space that tend to be more intimate than before (Zechner and Tiilikka, 2020). On the other hand, the father ponders that blog writing is a natural way to express feelings and experiences. In this way he defines himself as a modern man who understands his partner's needs and aspirations, even at the cost of his own privacy. The mother living in the United Kingdom is presented as being in need of support and communication channels, especially since it was difficult for them to have a child and the baby was born premature. Here, blogging serves to increase the 
well-being of the mother and to keep in contact with her friends and relatives in Finland. By supporting the blog writing, he points out his role as a caring partner and father. The differences in roles are visible, wherein the mother expresses feelings and the father gives rational support to the act of blogging and the contents of her writings, despite his initial doubts. Mothering is thus represented through a binary of a rational man and an emotional woman (see Jeremiah, 2006, p.24).

The division of labour between parents is rarely equal in Finland, although the common discourse is that equality is something that has already been achieved. Finnish mothers take care of the children more than the fathers, and they do most of the domestic tasks such as laundry and cooking (Ylikännö, Pääkkönen and Hakovirta, 2014). Time-use studies show that Finnish mothers of children under school age spend more time doing domestic work and childcare than fathers (Miettinen and Rotkirch, 2012). Studies also show that parents with young children may find it difficult to find time without children. The mother living in Denmark ironically describes the time spent in a Finnish supermarket as "quality time" for the entire family, and the episode is sketched out with irony, which is a common style in many blog texts (Pelevina, 2015).

For the wife it is not possible to enjoy quality time in the grocery store since she needs to remember the shopping list, baby's care bags, nappies and she may even need to breastfeed in the Prisma [supermarket] toilet. On top of that she is forced to bear her husband, who is cool as a cucumber. The man, on the other hand, genuinely enjoys the family togetherness, attention and the feeling of success: the toddler's basic security is at such a good level that s/he could have a tantrum even in a public space. So wonderfully Finnish. A Danish parent would have, from the first whine pushed a lollipop into the mouth of the child and would have worried about the forever lost reputation of the family. (Denmark)

In this extract there are explicit comparisons of how Danes and Finns handle children's tantrums in public spaces. The mother living in Denmark used the incident to portray the difference in the division of labour within families. In her view, Finnish fathers are able to have quality time in the middle of a busy and chaotic everyday life with young children, as the mother handles the practicalities. In a similar situation, Danish parents would have, according to the mother in Denmark, tried to steer clear from the approaching tantrum with the help of candy. The ways in which this model of behaviour by Danish parents is gendered is not reflected in the blog text. However, the Finnish way of parenting reflects in this excerpt the understanding of a child's need to be a young child, replete with tantrums that can happen in inconvenient places. At the same time, the mother living in Denmark ironically questions the equality of the division of labour between the parents.

\section{Conclusion}

By writing blogs that mix the two blog genres of "migrant" and "mommy" blogs, mothers build virtual bridges between two countries and societies. They make certain normative borders, which relate to mothering, visible and pay attention to non-existent ones at the same time. The normative borders of the welfare state manifest in the everyday lives of migrant mothers and their families, and, for example,there may be differences in the fat percentages of milk which are recommended for young children, the clothing children ought to wear, or the differences placed on the maternal body - the breasts or the pelvis that are given focus in maternity hospitals. A lack of borders is seen in instances of handling bullying at school or teaching English at an early age. The borders and the lack of borders in the blog texts show how parenting, mothering, and families are produced, interpreted, and reproduced in social encounters. Thus, the expectations concerning parenting change not only across the welfare states but also across time (Böök, 2010, p.90).

The society and its norms become visible when encountering services such as maternity hospitals and schools. Countries and welfare states support behaviours that are compatible with the country's economic and social systems. Generally, this means that countries wish to have citizens who educate themselves, are employed, pay taxes and their debts, and look after themselves and their close ones. How these aims are attempted to be achieved becomes evident in these service encounters. For example, according to the mother 
living in Turkey, responsible citizens are raised in school to be active and competitive in Turkey, whereas in Finland, everybody's equal participation is more strongly emphasized. This example shows how societal and welfare state norms become visible especially when they collide with the values, practices, and aims of the individuals concerned (see O’Reilly, 2008).

Within the study data, the mothering of these bloggers can be seen as liminal. They define themselves as both migrant Finns and mothers. At the same time, they are Finns not living in Finland and practicing their mothering in a context that spans nation states. Liminality indicates something that falls in-between or in a transitional state and having fluid boundaries (Lewiecki-Wilson and Cellio, 2011). Some of the mothers also indicate other positions that reflect their liminality, for example being a vegan, living in a reconstituted family, being a professional in education and a mother and nearly not being able to have a child. Maybe one of the motives to write blogs is to process these liminalities.

The discomfort and incompatibility of the differing norms across countries are visible in the blog texts. This is shown in the decision-making processes that were presented in the texts. The bloggers wanted to make their own choices that conformed to the norms of one or the other country, understandable and accept- able to the blog's readers. Especially, they are able to see, combine, and explain the variation of good parenthood in different cultures and contexts. This is part of the concept of representational mothering, and they make implicit comparisons between the ideology of intensive mothering and the realities of actual mothering (see Maher and Saugeres, 2007, p.6) in a transnational context. The often-ironic style of the blog texts can be seen as a textual style to attract and amuse readers, but this can also be seen as an acceptable way to handle differences and difficulties in a transnational everyday life that takes place across and between two countries and cultures (see Cappelli, 2008).

Despite the egalitarian ethos that the Finnish welfare state emphasizes, the division of labour seems to be traditional, and this was shown when searching for data for this study: blogs written by fathers were not to be found. In their texts, the mother bloggers are not giving fathers lead roles in parenting. Thus, the analysed texts represent the ideas of heterosexual intimate relationships and nuclear families, which can be seen as a norm of the "ideal family".

\section{References}

Altink, H. and Weedon, C., 2010. Introduction. In: J. Aaron, H. Altink and C. Weedon, eds. Gendering Border Studies. Cardiff: University of Wales Press, pp.1-16.

Baldassar, L. and Merla, L., eds., 2014. Transnational Families, Migration and the Circulation of Care: Understanding Mobility and Absence in Family Life. London: Routledge.

Baldock, J., 2007. On being a welfare consumer in a consumer society. Social Policy \& Society, 2(1), pp.6571.

Bassett, E.H. and O’Riordan, K., 2002. Ethics of internet research: Contesting the human subjects research model. Ethics and Information Technology, 4(3), pp.233-247.

Böök, M.L., 2010. Vastuulliseksi kasvamista, vastuun ottamista vai vastuussa olemista. Vanhempien näkemyksiä lasten vastuusta [Growing up to be responsible, taking responsibility or being responsible. Parents' opinions on children's responsibilities]. In: K.P. Kallio, A. Ritala-Koskinen and N. Rutanen eds. Missä lapsuutta tehdään? Helsinki: Nuorisotutkimusseura ry, pp.89-102.

Cappelli, G., 2008. “Expats’ talk”. Humour and irony in an expatriate’s travel blog. Textus, 21(1), pp.9-26.

Coffey, A. and Atkinson, P., 1996. Making Sense of Qualitative Data. Complementary Research Strategies. Thousand Oaks: Sage. 
Hiitola, J., 2015. Hallittu vanhemmuus. Sukupuoli, luokka ja etnisyys huostaanottoasiakirjoissa [Out-ofhome Placements and Gender, Class and Ethnicity]. Acta Universitatis Tamperensis 2026. Tampere: Tampere University Press. Available at: https:/tampub.uta.fi/bitstream/handle/10024/96664/978-951-449721-6p.pdf?sequence=1 [Accessed 15 June 2018].

Inman, A.G., Howard, E.E., Beaumont, R.L. and Walker, J.A., 2007. Cultural transmission: Influence of contextual factors in Asian Indian immigrant parents' experiences. Journal of Counseling Psychology, 54(1), pp.93-100.

Iseke-Barnes, J.M. and Danard, D., 2007. Indigenous knowledges and worldview: Representations and the internet. In: J.M. Iseke-Barnes, and D. Danard, eds. Information Technology and Indigenous People. Hershey: IGI Global, pp.470-477.

Jeremiah, E., 2006. Motherhood to mothering and beyond. Maternity in recent feminist thought. Journal of the Association for Research on Mothering, 8(1-2), pp.21-33.

Julkunen, R., 2017. Muuttuvat hyvinvointivaltiot. Eurooppalaiset hyvinvointivaltiot reformoitavina [Changing Welfare States. European Welfare States to be Reformed]. Jyväskylä: SoPhi. Available at: https://jyx.jyu.fi/bitstream/handle/123456789/55748/978-951-39-7146-5.pdf?sequence=1\&isAllowed=y [Accessed 18 March 2019].

Kildal, N. and Kuhnle, S., 2005. Introduction. In: N. Kildal and S. Kuhnle, eds. Normative Foundations of the Welfare State. The Nordic Experience. Abingdon: Routledge, pp.1-9.

Knuuttila, T. and Lehtinen, A.P., 2010. Johdanto: Representaatio - tiedon kivijalasta tieteiden työkaluksi [Introduction: Representation -from the foundation of knowledge into a tool of science]. In: T. Knuuttila and A.P. Lehtinen, eds. Representaatio. Helsinki: Gaudeamus, pp.7-34.

Kremer, M., ed., 2007. How Welfare States Care. Culture, Gender and Parenting in Europe. Amsterdam: Amsterdam University Press.

Lewiecki-Wilson, C. and Cellio, J., 2011. Introduction. On liminality and cultural embodiment. In: C. Lewiecki-Wilson and J. Cellio, eds. Disability and Mothering. Liminal Spaces of Embodied Knowledge. New York: Syracuse University Press, pp.1-16.

Lopez, L.K., 2009. The radical act of "mommy blogging”: Redefining motherhood through the blogosphere. New Media \& Society, 11(5), pp.729-747

Maher, J. and Saugeres, L., 2007. To be or not to be a mother? Women negotiating cultural representations of mothering. Journal of Sociology, 43(1), pp.5-21.

Miettinen, A. and Rotkirch, A., 2012. Yhteistä aikaa etsimässä. Lapsiperheiden ajankäyttö 2000-luvulla [Looking for Common Time. Use of Time for Families With Children in the 21st Century.]. E 42. Helsinki: Väestöliitto.

Opetus- ja kulttuuriministeriö, 2018. Kieltenopetus alkaa jatkossa jo ensimmäiseltä luokalta $-4,3$ miljoonaa valtionavustuksia jaettu [Language Teaching Starts in the Future From the First Grade -4.3 Million State Support Given]. Helsinki: OKM. Available at: https://minedu.fi/artikkeli/-/asset_publisher/kieltenopetusalkaa-jatkossa-jo-ensimmaiselta-luokalta-4-3-miljoonaa-valtionavustuksia-jaettu [Accessed 23 October 2018].

O’Reilly, A., 2008. Introduction. In: A. O’Reilly, ed. Feminist Mothering. Albany: State University of New York Press, pp.123. 
Pelevina, N., 2015. Asiantuntijamme Idässä. Identifikaatioita, toiseuksia ja asiantuntijuuksia ulkosuomalaisten blogeissa Kiinassa, Japanissa, Qatarissa, Saudi Arabiassa, Israelissa, Turkissa ja Venäjällä [Our Experts in the East. Identification, Otherness and Expertise in the Blogs of Migrant Finns in China, Japan, Qatar, Saudi Arabia, Israel, Turkey, and Russia]. Master’s Thesis in political history. Helsinki: University of Helsinki. Available at:

https://helda.helsinki.fi/bitstream/handle/10138/157853/pelevina_poliittinenhistoria.pdf?sequence=2 [Accessed 4 November 2018]

Perälä-Littunen, S., 2004. Cultural images of a good mother and a good father in three generations. Jyväskylä Studies in Education, Psychology and Social Research, 239. Jyväskylä: University of Jyväskylä. Available at: https://jyx.jyu.fi/bitstream/handle/123456789/13379/1/9513917797.pdf [Accessed 3 February 2019].

Popow, M., 2016. The meanings of learning as described by Polish migrant bloggers. Australian Journal of Adult Learning, 56(3), pp.332-352.

Smeds, V., 2017. Lapset kylmässä. Lasten talvivaatetus Suomen arktisissa oloissa [Children in the Cold. Children's Winter Clothing in Finnish Arctic Conditions]. Master's Thesis. Rovaniemi: University of Lapland. Department of Clothing Design. Available at: http://urn.fi/URN:NBN:fi:ula-201709281325 [Accessed 4 November 2018]

Strandbu, Å., 2005. Identity, embodied culture and physical exercise stories from Muslim girls in Oslo with immigrant backgrounds. Young. Nordic Journal of Youth Research, 13(1), pp.27-45.

Tourula, M., Isola, A. and Hassi, J., 2008. Children sleeping outdoors in winter: Parents' experiences of a culturally bound childcare practice. International Journal of Circumpolar Health, 67(2-3), pp.269-278.

Vuori, J., 2003. Äitiyden ainekset [The ingredients of motherhood]. In: H. Forsberg and Nätkin, eds. Perhe murroksessa. Kriittisen Perhetutkimuksen Jäljillä. Helsinki: Gaudeamus, pp.39-63.

Wall, L., 2001. Moral constructions of motherhood in breastfeeding discourse. Gender \& Society, 15(4), pp.592-610.

Wright, S., 2016. Conceptualising the active welfare subject: Welfare reform in discourse, policy and lived experience. Policy and Politics, 44(2), pp.235-252.

Ylikännö, M., Pääkkönen, H. and Hakovirta, M., 2014. Time use of Finnish fathers - Do institutions matter? In: G.B. Eydal and T. Rostgaard, eds. Fatherhood in the Nordic Welfare States: Comparing Care Policies and Practice. Bristol: Policy Press, pp.103-120.

Zechner, M. 2017. Transnational habitus at the time of retirement. Identities. Global Studies in Culture and Power 24(5), pp. 573-589.

Zechner, M. and Tiilikka, T., 2020. Hyvinvointivaltio kotiseutuna ulkosuomalaisten blogeissa [Welfare state as a homely landscape in the blogs of migrant Finns]. In: Riukulehto and A. Haasio, eds. Virtuaalinen Kotiseutu. Helsinki: Suomalaisen Kirjallisuuden Seura, forthcoming.

\section{Data}

Denmark: Jyllannin Suomineito https://www.vauva.fi/blogit/jyllannin-suomineito/

France: Lily http://www.lily.fi/blogit/petit-ange

The Netherlands: Hollanninsuomalainen https://hollanninsuomalainen.fi 
Turkey: Ulkosuomalaisen äidin merkintöjä

http://ulkosuomalainenaiti.blogspot.fi/search/label/lastenhoitoa\%20turkkilaisittain

United Kingdom: Shitty is the new black https://www.vauva.fi/blogit/shitty-new-black 